\title{
Akademisyenlerin Akademik Sosyal Ağlara Yönelik Tutumları: Ankara Üniversitesi Örneği ${ }^{*}$
}

\section{Academicians' Attitudes towards Academic Social Networking Sites: The Case of Ankara University}

\section{Demet Işık*** ve Özlem Gökkurt Demirtel $^{\text {**** }}$}

$\ddot{O} z$

Bilimsel iletişimin değişen dinamikleri, genel anlamda araştırmacıların özelde akademisyenlerin araştırma yapma, araştırma sonuçlarını yayımlama ve paylaşma gibi bilimsel iletişim süreçlerini değiştirmiştir. Günümüzde akademisyenler görünürlüklerini ve etkinliklerini artırmak, yayınlarını duyurmak ve paylaşmak için sosyal ağları ve akademik sosyal ă̆ları kullanmaktadırlar. Sosyal bir ăga, akademik içeriğin ve akademik faaliyetlerin eklenmesi ile ortaya çıkan akademik sosyal ağlar, araştırmacılara ve akademisyenlere çeşitli yararlar sağlamaktadır. Amaç: Çalışmada, Ankara Üniversitesi akademisyenlerinin akademik sosyal ağlara ilişkin tutumlarını ve akademik sosyal ağlardan ne ölçüde yararlandıklarını ortaya çıkarmak amaçlanmıştır. Yöntem: Nicel bir araştırmaya örnek olan bu çalışmada, tarama (survey) tekniğinden yararlanılarak veriler toplanmıştır. Bulgular: 560 akademisyenin katıldı̆̆ı anket sonucunda elde edilen bulgulara göre akademisyenlerin \%82,7'sinin (463 kişi) akademik sosyal ă̆ları kullandiğı belirlenmiştir. En çok tercih edilen akademik sosyal ă̆ların Google Scholar, ResearchGate ve Academia.edu olduğu tespit edilmiştir. Akademisyenler, akademik sosyal ağları en çok alanlarıyla ilgili yayınları ve yenilikleri takip etmek ve akademik çalışmaları paylaşmak için kullanmaktadırlar. Akademisyenlerin akademik sosyal ăg kullanım durumlarının cinsiyet ve unvan değişkenlerine göre büyük ölçüde benzerlik gösterdiği fakat fakültelerine ve yaş gruplarına göre anlaml düzeyde farklılaştı̆̆ tespit edilmiştir. Sonuç: Ankara Üniversitesi akademisyenlerinin çoğunluğunun akademik sosyal ă̆ları kullandığı ve dolayısıyla akademisyenlerin akademik sosyal ă̆lar konusunda farkındalı̆̆ının olduğu sonucuna ulaşılmıştır. Ancak akademisyenler düzenli kullanım sağlamada, geri bildirimleri takip etmede ve yayın isteklerini karşılamada zorlanmaktadırlar. Özgünlük: Uluslararası literatürde akademik sosyal ăglar ve yararlarının araştırıldiğı pek çok çalışma bulunmaktadır. Fakat yerel literatür incelendiğinde akademik sosyal ă̆ları ele alan sinırlı sayıda çalışma

\footnotetext{
${ }^{*}$ Bu makale, 2020 yılında Demet Işık tarafından Ankara Üniversitesi Sosyal Bilimler Enstitüsü Bilgi ve Belge Yönetimi Anabilim Dalında tamamlanan "Bilimsel iletişimde akademisyenlerin değerlendirilmesinde akademik sosyal ağların ve altmetrik göstergelerin kullanımı: Ankara Üniversitesi örneği” başlıklı doktora tezine dayanarak hazırlanmıştır.

** Ankara Üniversitesi, Bilgi ve Belge Yönetimi Bölümü. Ankara, Türkiye. E-posta: demet1ki@gmail.com Ankara University, Department of Information and Records Management, Ankara, Turkey. E-mail: demet1ki@gmail.com

*** Ankara Üniversitesi, Bilgi ve Belge Yönetimi Bölümü. Ankara, Türkiye. E-posta: ozlem.gkurt@gmail.com Ankara University, Department of Information and Records Management, Ankara, Turkey. E-mail: ozlem.gkurt@gmail.com
}

Geliş Tarihi - Received: 03.02.2021

Kabul Tarihi - Accepted: 27.06.2021

Yayımlanma Tarihi - Published: 30.06.2021 
olduğu tespit edilmiştir. Bu açıdan yapılan araştırma, özgün ve yerel literatürde konuyu tartışması açısından önemli bir çalışmadır.

Anahtar Sözcükler: Sosyal ă̆lar; akademik sosyal ăglar; bilimsel iletişim; akademisyenler; akademik etki.

\begin{abstract}
The changing dynamics of scholarly communication have changed the scholarly communication processes of researchers in general, especially of academicians, such as conducting research, publishing and sharing research results. Today, academicians use social networks and academic social networking sites to increase their visibility and effectiveness, to announce and share their publications. Academic social networking sites created by adding academic content and academic activities to a social network; it provides various benefits to researchers and academicians. Objective: In this study, it is aimed to reveal the attitudes of Ankara University academicians towards academic social networking sites and to what extent they benefit from academic networking sites. Method: In this study, which is an example of quantitative research, data were collected using the survey technique. Findings: According to the findings obtained as a result of the survey participated by 560 academicians, it was determined that $82.7 \%$ of the academicians (463 people) used academic social networking sites. It has been determined that the most preferred academic social networking sites are Google Scholar, ResearchGate and Academia.edu. Academicians use academic social networking sites mostly for the purposes of following publications and innovations in their field and sharing academic studies. It was determined that academic social networking sites usage situations of academicians were similar to a great extent according to gender and title variables, but differed significantly according to their faculties and age groups. Implications: It was concluded that the majority of Ankara University academicians use academic social networking sites and therefore they have awareness of these sites. However, while using academic social networking sites the academicians have difficulties in providing regular use, following feedback, and meeting publication requests. Originality: There are many studies in the international literature investigating academic social networking sites and their benefits. However, when the local literature was examined, it was found that there were a limited number of studies dealing with academic social networking sites. In this respect, the research is a distinctive and significant study in terms of discussing the subject in local literature.
\end{abstract}

Keywords: Social networks, academic social networking sites; scholarly communication; academicians, academic impact.

\title{
Giriş
}

Sosyal ağlar, araştırmacıların ve akademisyenlerin akademik çalışmalarını paylaştıkları ortamlar olarak akademik sosyal ağların ortaya çıkmasına zemin hazırlamıştır. Sosyal ağ (SA) siteleri, insanların başkalarıyla kolayca bağlantı ve iletişim kurmasını sağlayan platformlardır (Jordan, 2019, s. 1). Bu siteler, dünyanın geri kalanıyla etkileşime girmek için popüler bir platform haline geldiğinden (Yu ve diğerleri, 2016, s. 1002), akademik toplulukta da giderek daha fazla önem kazanmaktadır (Ortega, 2015, s. 520). SA siteleri, "bireylerin (1) sinırlı bir sistem içinde genel veya yarı genel bir profil oluşturma, (2) bağlantı paylaştıkları diğer kullanıcıların bir listesini verme ve (3) bağlantı listesini ve sistem içinde başkaları tarafından 
yapılan bağlantıları görüntüleme" (Boyd ve Ellison, 2007, s. 211) faaliyetlerine yönelik web tabanlı hizmetler olarak tanımlanmaktadır. Sosyal medya, insanların iletişim kurma, bilgi dağıtma, fikir alışverişinde bulunma ve arkadaş edinme biçimlerini değiştirmiştir (Yu ve diğerleri, 2016, s. 1002). Boyd ve Ellison'a (2007, s. 211) göre "sosyal ă̆ sitelerini benzersiz kılan, bireylerin yabancılarla tanışmasına izin vermelerinden ziyade kullanıcıların bir araya gelerek sosyal ağlarının görünür hale gelmesini sağlamalarıdır”. Genel olarak araştırmacılar, sosyal medyayı, araştırmalarının akranları tarafından daha kolay keşfedilebilmesini sağlamak (Kelly ve Delasalle, 2012) ve dolayısıyla akademik anlamda görünürlüklerini artırmak için kullanma eğilimindedirler. Sosyal medya ve ağ sitelerinin bilimsel kullanımı ile ilişkili sıkça atıfta bulunulan ve genel kullanım eğilimini de içeren yararları aşağıdaki gibidir (Gruzd, 2012, s. 22):

1. Akademisyenlerin yeni bağlantılar keşfetmesine ve kurmasına yardımcı olmak,

2. Mevcut bağlantıları güçlendirmek ve sürdürmek,

3. Araştırma topluluklarındaki en son araştırmalardan haberdar olmak,

4. Çalışmalarını akranları ve genel olarak halk arasında tanıtmak.

SA'lar her kesimden kullanıcıya hitap ettikleri için genel kullanıcılarının yanı sıra araştırmacıların ağlarını oluşturma ve kendilerini tanıtma olanaklarını yakaladıkları platformlar olarak da hizmet etmiştir. Daha sonra bir dizi web sitesi, yayınlarını yönetmek, paylaşmak, teşvik etmek ve işbirliği fırsatları aramak için araştırmacılara ve kurumlara platformlar sağlamıştır (Yu ve diğerleri, 2016, s. 1002). Bunlar akademik çalışma yapan bireylere özel, akademik sosyal ağ (ASA) olarak adlandırılan platformlardır. ASA'lar ortaya çıkmış olsa da araştırmacı ve akademisyenler yine SA'ları akademik çalışmalarını duyurmak, tanıtmak ya da akademik tartışmalar yapmak için kullanmaktadırlar. Ancak ASA'lar, hem sosyal hem de akademik ă̆ olma özellikleriyle araştırmacılara ve akademisyenlere görünürlüklerini bilim dünyasında artırma, yayınlarını/etkinliklerini duyurma ve tanıtma firsatını sunmaktadır. Mevcut durumda akademisyenlerin mesleki değerlendirmeleri genellikle atıf sayıları üzerinden yapılmaktadır. Yayınlarına atıf yapılma potansiyelini artıran ister akademik ister akademik olmayan ağlar olsun, araştırmacı ve akademisyenler bu ortam ya da platformlara kendilerine ve kariyerlerine yarar sağlayan araçlar olarak bakabileceklerdir. Atıf etkisi, akademisyenleri çalışmalarını tanıtmak üzere akademik topluluğun ve genel toplumun görüşlerine sunmaya iten bir gerçekliktir. Mevcut durum, ağ çağında bilimsel iletişimin yeni araçlar üretmesini kaçınılmaz kılmıştır. Böylece akademik çalışma yapanlara özel ASA'lar oluşturulmuştur.

ASA'lar akademik makaleleri veya makale özlerini yüklemeye veya bunlara bağlantılar vermeye izin verir; ayrıca makaleler için talebi izlemeyi ve profesyonel etkileşimde bulunmayı sağlar. Bunlara ek olarak kullanıcılarına tartışma ortamı sunar ve soru-cevap alışverişinde bulunmaya olanak sağlar (Meishar-Tal ve Pieterse, 2017, s. 1). Her bir ASA'nın özellikleri farklı olmakla beraber akademik tartışma ve yayın paylaşma platformu olma özellikleri ortaktır. Araştırmacılar ve akademisyenler arasında en iyi bilinen ve en çok kullanılan ASA'lara ResearchGate, Academia.edu ve Mendeley örnek verilebilir. ASA'lar öncelikle profil oluşturma ve bağlantıyı kolaylaştırma için geliştirilen (Facebook'a benzer; örnekler arasında Academia.edu ve ResearchGate vardır) ve birincil olarak akademik içeriği yayımlama ile paylaşmaya odaklanan ve daha sonra sosyal ağ yeteneklerini (Mendeley gibi) ekleyen platformlar olarak (Jordan, 2019, s. 2) iki kategoriye ayrilabilir. 
ASA'ları anlamak önemlidir, böylece akademisyenler yeni teknolojilere uyum sağlayabilir ve gerekirse benimseyebilirler (Thelwall ve Kousha, 2014, s. 721). Bilimsel iletişim süreçlerine dâhil olan ASA'ların bilimsel iletişimi değiştirme ve ona yön verme potansiyeli vardır. Bu potansiyele sahip ağların sağladığı yararlar literatürde; çevrim içi kişisel bilgilerin yönetimi, araştırmanın yayılması, işbirliği, doküman yönetimi ve etki ölçümü (Espinoza Vasquez ve Caicedo Bastidas, 2015; Meishar-Tal ve Pieterse, 2017) olmak üzere beş grupta değerlendirilmektedir. Bu işlevlere 'açık erişime destek' maddesi de eklenebilir.

Milyonlarca kullanıcısıyla ASA'lar, bilimsel iletişim ve akademik bilgi arayan ekosisteme önemli bir katkı sunar. Bu nedenle oynadıkları rolü ve varsa akademik kariyer dinamiklerinde yapabilecekleri değişiklikleri anlamaya gereksinim vardır (Thelwall ve Kousha, 2014, s. 721). ASA'ları değerlendirmek ve kullanabilmek için onların özelliklerini ve araştırmacılara sağladığı araçları bilmekte yarar vardır. ASA'lar, platformlarında kullanıcılarına ya da üyelerine profil ekleme olanağı sunmaktadır. Profiller üyelerin temel bilgilerini içerir ve kullanıcıya kendilerini ve çalışmalarını tanıtmaları için bir alan sağlar. ASA'lar, akademik dünyada bilgi yayınlama ve paylaşım örüntülerinde devrim yapma potansiyeline sahiptir. Dünyadaki akademisyenler arasındaki ilişkiler için platformlar sunarak, araştırma topluluğunun yapısını ve dinamiğini etkileyebilir (Meishar-Tal ve Pieterse, 2017, s. 3). Bir araştırmacının alanı ile ilgili çalışmaları ve aynı alandaki diğer araştırmacıları ASA'lar aracılığıyla bulması, geleneksel yöntemlerle işbirliği ortamı oluşturması ile karşılaştırıldığında kolaylaşabilmektedir. ASA'larda sadece bilimsel dergilerde yayımlanan hakemli makaleler yer almaz; taslaklar, ders notları, ön baskılar, hazırlık aşamasındaki dokümanlar da yer alır. $\mathrm{Bu}$ açıdan bakıldığında, ASA'lar bir araştırmacının her türden bilimsel çıktısını depolayabileceği bir çevrim içi platform görevi de üstlenir. ASA'ların ortaya çıkışı, yükselişis ve gelişimi, açık erişim yoluyla bilginin yayılması ilkeleriyle yakından bağlantılıdır (Williams ve Woodacre, 2016, s. 283). ASA'lar akademik yayıncılığın bu ortamlara kaymasına, yayın sürelerinin kısalmasına ve yayın öncesindeki taslakların ya da ders notlarının paylaşılmasına ve halka açık hale getirilmesine olanak sağlayarak açık erişime de katkı sunmaktadır (Meishar-Tal ve Pieterse, 2017, s. 3). ASA'lar aracılığıyla oluşturulan ağlar, bilim insanları arasında bağlantı kurularak erişilmesi zor veriler veya yayınlar gibi değerli materyallerin etkin bir şekilde kitlesel olarak kullanımına olanak sağlayabilir (Williams ve Woodacre, 2016, s. 284).

Günümüzde, kişisel sayfalar oluşturma şansını getiren Web'in ve ASA'ların ortaya çıkmasıyla, araştırmacılar çalışmalarını çeşitli zengin kanallar ve elektronik formatlar aracılığıyla sunmaya başladılar (Martín-Martín, Orduna-Malea, Ayllón ve Delgado LópezCózar, 2016, s. 22-23). Böylelikle ASA'ların, bilimsel iletişim sürecinde kullanılan bir araç haline geldiği söylenebilir. Bilimsel iletişim süreçleri arasında yer alan paylaşım ve yayma olgusu, ASA'lar aracılığıyla gerçekleştirilebilmekte, mevcut ASA'lar dünyada popülerliğini her geçen gün artırmaktadır.

\section{Literatür İncelemesi}

Uluslararası düzlemde ASA'lara ilişkin pek çok çalışma bulunmaktadır. Bunlar; (1) ASA'lardan birkaçına yer vererek bu ağların çeşitli yönlerinin karşılaştırıldığı çalışmalar, (2) akademisyenlere odaklanan ve akademisyenlerin ASA kullanımları ile ilgili görüşlerinin anket yoluyla (survey) ya da görüşmelerle alındığı araştırmalar ve (3) bir ASA'nın seçilerek bu ağ 
üzerindeki profillerin incelenip verilerin toplandığı ve analizlerin yapıldığı çalışmalar şeklinde üç grupta değerlendirilebilir. Mevcut araştırmada, 2. grupta değerlendirilen çalışmalara odaklanılmıştır.

ASA'larla ilgili yapılan en kapsamlı ve bu alanda temel teşkil eden (Jordan, 2019) çalışmada (Van Noorden, 2014), bilim insanlarının neden sosyal medyayı kullandığı araştırılmıştır. 95 ülkeden 3.500 bilim insanının yanıtlarına dayanan anket ile verilerin toplandığı araştırmada, en çok tanınan ve ziyaret edilen bilimsel sosyal medya ağının Google Scholar olduğu ve bunu ResearchGate'in izlediği sonucuna ulaşılmıştır. Bu ağları LinkedIn ve Facebook takip etmektedir. Mendeley ve Academia.edu tanınırlığ 1 ve ziyaret sıklığı açısından son siralarda yer almaktadır (Van Noorden, 2014, s. 127).

Uluslararası düzeyde akademisyenlerin SA kullanımlarını inceleyen Lupton (2014), akademisyenlerin çoğunluğunun Academia.edu, ResearchGate ve sosyal medyayı kullanma konusunda olumlu görüş bildirdiklerini fakat bir dizi endişelerini de dile getirdiklerini belirtmektedir. Bunlar arasında gizlilik, kişisel ve profesyonel kullanım arasındaki sınırların bulanıklaşması, akademik kariyerin sosyal medyanın haksız kullanımı nedeniyle tehlikeye girme riski, güvenilirlik sorunu, yayınlanan içeriğin kalitesi vb. yer almaktadır. ASA'ların kullanımıyla ilgili akademisyenlerin temel kaygılarının güven ve gizlilikle ilgili kaygılar olduğu başka bir çalışmada da bildirilmiştir (Salahshour, Dahlan ve Iahad, 2016, s. 97).

SA ve ASA kavramlarını içerecek şekilde sosyal medya kullanımlarının incelendiği bir diğer çalışmada (Manca ve Ranieri, 2016, s. 63), sonuçlar sosyal medya kullanımının hâlâ oldukça sınırlı, kısıtlı olduğunu ve kullanım sıklığı ile en çok ilişkili değişkenin bilimsel disiplin olduğunu göstermektedir. Ayrıca, yaş ve kıdem SA’ların benimsenmesini etkilemektedir. Çalışmanın sonuçları; öğretim üyelerinin sosyal medyayı öğretim uygulamalarına dâhil etmekten çok kişisel paylaşım ve meslektaşlarla profesyonel bağlantılar için benimsemeye eğilimli olduklarını, e-öğrenme veya karma öğrenme ile ilgili önceki deneyimlerin sosyal medya kullanımıyla büyük ölçüde ilişkili olduğunu da göstermektedir.

ASA'lara erişimin birincil nedeninin, web sitesinde makale aramak olduğunu ve akademisyenlerin çoğunun sirasıyla ResearchGate, Academia.edu ve Google Scholar'1 kullanmayı tercih ettiğini bildiren çalışma (Ali ve Richardson, 2018, s. 28), Pakistan'da 5 devlet üniversitesinde sosyal bilimler fakültelerindeki akademisyenlerin yanıtlarına dayanmaktadır. $\mathrm{Bu}$ araştırma, akademisyenlerin \%80'inden fazlasının birden fazla ASA'yı kullandıklarını ve bu ağlara yayınlarını yükleyen akademisyenlerin öncelikli olarak atıf sayılarını artırma amacında olduklarını belirlemiştir. Akademisyenlerin ASA kullanım durumları ile bu sitelerin algılanan faydalarını inceleyen ve İsrail'de gerçekleştirilen çalışma (Meishar-Tal ve Pieterse, 2017, s. 17), akademisyenlerin ASA'ları temel olarak bilgi edinme, paylaşma ve diğerleriyle etkileşim için kullandığını göstermektedir.

Hindistan'da gerçekleştirilen iki çalışmada (Asmi ve Margam, 2018, s. 98; Madhusudhan, 2012, s. 107), en çok kullanılan ASA'ların sırasıyla ResearchGate ve Academia.edu olduğu tespit edilmiştir. Çeşitli çalışmalarda akademisyenler ASA'ları zaman alıcı bulduklarını ifade etmişlerdir (Asmi ve Margam, 2018, s. 101; Chakraborty, 2012, s. 23). Facebook ve ResearchGate kullanan araştırmacıların katıldığı ve Hindistan menşeili çalışmada (Chakraborty, 2012, s. 22); araştırmacıların, ResearchGate'i çalışma grupları oluşturmak, güncel kalmak, başkalarının araştırma alanını tespit etmek ve araştırmalarını paylaşmak için 
kullandıkları belirlenmiştir. İki ASA'nın kullanım nedenlerini de inceleyen çalışmanın (Asmi ve Margam, 2018, s. 104) tespiti "ResearchGate diğer bilim insanları ile iletişim kurmak için kullanılırken Academia.edu araştırmaları paylaşmak ve takip etmek için kullanılmaktadır”, şeklindedir.

Araştırmacıların ASA kullanımlarına yönelik farkındalık, tutum ve algılarının araştırıldığ1 çalışmalarda (El-Berry, 2015; Elsayed, 2016; Sheikh, 2017), katılımcıların ASA'ların farkına vardıkları ve birden fazla ASA'nın üyesi oldukları tespit edilmiştir. Araştırmacılar, platformları çoğunlukla uzmanlarla etkileşimde bulunmak, araştırma çıktılarını tanıtmak/paylaşmak, tartışmalara katılmak, en yeni araştırma eğilimleri hakkında fikir edinmek ve araştırma problemlerini çözmede yardım almak için kullandıklarını belirtmişlerdir. LinkedIn en yüksek kullanım düzeyinde yer alıp bu ağı sırasıyla ResearchGate, Academia.edu, Mendeley ve Zotero takip etmektedir (Sheikh, 2017, s. 188). El-Berry (2015, s. 120) tarafindan geçekleştirilen çalışmada ResearchGate'in en yüksek farkındalık ve kullanım seviyesine sahip olduğu, bu ağı sirasiyla LinkedIn, Academi.edu, Mendeley ve Scholastica'nın izlediği görülmüştür. Elsayed (2016, s. 383), araştırmasında ResearchGate'in en sık kullanılan ağ olduğunu bildirmiştir. En popüler ASA'ların ResearchGate ve Academia.edu olduğunu fakat akademisyenler arasında ASA kullanım oranının düşük olduğunu bildiren çalışmada (Salahshour, Dahlan ve Iahad, 2016, s. 97) ayrıca cinsiyet, yaş, pozisyon, disiplin ve deneyim değişkenleri arasında ASA'ların kullanımı üzerinde sadece akademik pozisyon değişkeninin etkili olduğu tespit edilmiştir. ASA'lara makalelerini yükleyen akademisyenlerin bunu, makalelerin kullanılabilirliğini ve yayılmasını arttırmak için yaptıkları, ayrıca ASA'ların araştırmayı yaygınlaştırdığı ve atıfları artırmaya yardımcı olduğu görüşlerine katıldıkları, Finlandiya-Hanken Ekonomi Okulu kapsamında yürütülen çok yöntemli bir vaka çalışması sonucunda tespit edilmiştir (Laakso, Lindman, Shen, Nyman ve Björk, 2017, s. 130).

Academia.edu'nun akademisyenler üzerindeki etkilerinin araştırıldı̆̆ sonuçlara ulaşılan çalışmalarda (Nández ve Borrego, 2013; Megwalu, 2015) veriler Academia.edu'dan elde edilmiş ve anket yöntemiyle akademisyenlerden veri toplanmıştır. Megwalu (2015, s. 185); fizik, dilbilim ve sosyoloji araştırmacılarının Academia.edu sitesinde iletişim davranışlarını ve siteyi kullanımlarının profesyonel faaliyetlerine yönelik etkisini araştırdığı çalışmasında, Academia.edu kullanımının, akademisyenlerin bağlı oldukları disipline, mesleki statülerine ve yılın zamanına bağlı olarak değiștiğini göstermektedir. $\mathrm{Bu}$ çalışmada fizikçilerin aksine, dilbilimcilerin ve sosyologların Academia.edu ve diğer ASA'ları kullanmaya daha yatkın oldukları sonucuna ulaş1lırken, Nández ve Borrego (2013, s. 789) sosyal bilimler akademisyenlerinin yoğun olarak Academia.edu'yu kullandığ sonucuna varmıştır.

Mendeley kullanan akademisyenlerin kullanım alışkanlıklarının ve gruplara katılma motivasyonlarının araştırıldığı çalışmanın sonuçları, katılımcıların araştırma temelli özelliklerle meşgul oldukları kadar sosyal ve temel özelliklere katılmadıklarını ve daha fazla gruba katılan kullanıcıların profesyonel görünürlüğünü artırmak için daha güçlü bir motivasyona sahip olduklarını, okudukları araştırma makalelerini grup okuma listelerine eklediklerini (Jeng, He ve Jiang, 2015, s. 890) göstermektedir.

Yerel düzlemde ASA'ları konu alan ilk çalışmada (Güler ve Mutlu, 2013, s. 77); akademisyenlerin ASA'ları kullanma düzeyinin yüksek olmadığı gözlenmiştir. İkinci 
çalışmada (Bardakcı, Arslan ve Kocadağ Ünver, 2018), ASA'ların akademisyenler tarafından yaygın olarak kullanılmasına rağmen katılımcıların çoğunluğunun bunları diğer araştırmacılarla işbirliği kurmak için bir bilgi edinme yolu olarak görmedikleri sonucuna ulaşılmıştır. Üçüncü çalışmada (Işsk ve Gökkurt Demirtel, 2020, s. 69-70) ise Bilgi ve Belge Yönetimi alanında çalışan akademisyenlerin SA'lar konusunda olumsuz bir yaklaşıma sahip olmalarına rağmen çoğunluğunun SA'ları ve ASA'ları kullandıkları bildirilmiştir.

Literatür genel olarak değerlendirildiğinde akademisyenlerin ASA kullanma nedenlerine ve en sık kullanılan ASA'ların belirlenmesine odaklanıldığı görülmektedir. ResearchGate ve Academia.edu'nun dünyada yaygın olarak kullanılan ASA'lar olarak öne çıtı̆ğ akademisyenlerin ASA'lar konusunda farkındalıklarının bulunduğu, ASA kullanımında disiplinlere göre farklılıklar olduğu yapılan çalışmalarda tespit edilmiştir.

\section{Araştırmanın Amacı ve Araştırma Soruları}

Araştırmada; günümüzde bilimsel iletişim sürecinde önemli bir rol oynayan ASA'lar hakkında bilgi vermek, Ankara Üniversitesi (AÜ) akademisyenlerinin ASA'ları kullanım durumlarını ortaya çıkarmak amaçlanmaktadır. Bu amaç doğrultusunda, araştırma soruları aşağıdaki gibi oluşturulmuştur:

1. AÜ akademisyenlerinin ASA'ları kullanım düzeyleri nedir?

2. AÜ akademisyenlerinin SA ve ASA kullanımlarında unvanlarına ve fakültelerine göre bir farklılık bulunmakta midır?

3. AÜ akademisyenleri hangi ASA'ları kullanmaktadırlar?

4. AÜ akademisyenleri ASA'ları hangi amaç/lar için kullanmaktadırlar?

5. AÜ akademisyenlerinin ASA'ların sunduğu altmetrik göstergelere önem verme derecesi nedir?

6. ASA'ları kullanmayan AÜ akademisyenlerinin ASA'ları kullanmama nedenleri nelerdir?

7. ASA'ları kullanan AÜ akademisyenleri hangi konularda zorlanmaktadırlar?

8. AÜ akademisyenlerinin ASA'lar konusunda eğitim gereksinimi bulunmakta mıdır?

\section{Araştırmanın Kapsamı ve Yöntemi}

Araştırmanın kapsamını, bilimsel iletişimde yaşanan değişimlerin ortaya çıkardığı ASA'ların tartışılması ve incelenmesi oluşturmaktadır. Bu kapsamda, ASA kavramına ilişkin tarihsel süreç, yaygın olarak kullanılan ASA'lar, araştırmacılara sunduğu yararlar hakkında kavramsal içerik sunulmuştur. Araştırmanın uygulama kısmı ise, Ankara Üniversitesi (AÜ) bünyesindeki akademisyenler kapsamında yürütülmüştür.

$\mathrm{Bu}$ araştırma genel anlamda nicel araştırma türüne bir örnektir. Nicel araştırmalar kapsamında tanımlanan araştırma türleri açısından bakıldığında bu çalışma, tarama (survey) araştırması özelliklerini taşımaktadır. Bir grubun belirli özelliklerini belirlemek için verilerin toplanmasını amaçlayan çalışmalara tarama (survey) araştırması denir (Büyüköztürk, Kılıç Çakmak, Akgün, Karadeniz ve Demirel, 2016, s. 14). Bu bağlamda akademisyenlerin ASA'lar hakkında görüşlerini almak ve bu ağları kullanımları hakkında veri toplamak için anket tekniğinden yararlanılmıştır. AÜ akademisyenlerine uygulanan anket ile elde edilen bulgular analiz edilmiştir. 


\section{Evren ve Örneklem}

Araştırmanın örneklemini AÜ fakültelerinde görev yapan akademisyenler oluşturmaktadır. AÜ Personel Daire Başkanlığından 25.09.2019 tarihinde elde edilen verilere göre araştırmanın evreni, 3.164 akademik personelden oluşmaktadır. Evrende yer alan fakülteler ve her fakültedeki akademik personelin unvanlara göre dağılımı Tablo 1'de yer almaktadır.

Tablo 1

Evrende Yer Alan Birimler ve Akademik Personel Sayıları

\begin{tabular}{lcccccc}
\hline Fakülteler & Prof.Dr. & Doç.Dr. & $\begin{array}{c}\text { Dr.Öğr. } \\
\text { Üyesi }\end{array}$ & Arş.Gör. & Öğr.Gör. & Toplam \\
\hline Dil ve Tarih-Coğrafya Fakültesi & 127 & 31 & 64 & 89 & 17 & 328 \\
\hline Diş Hekimliği Fakültesi & 63 & 5 & 1 & 95 & 8 & 172 \\
Eczacılık Fakültesi & 46 & 11 & 15 & 47 & 1 & 120 \\
\hline Eğitim Bilimleri Fakültesi & 31 & 22 & 21 & 28 & 14 & 116 \\
Fen Fakültesi & 94 & 24 & 23 & 46 & 15 & 202 \\
Güzel Sanatlar Fakültesi & 1 & 1 & 4 & 2 & 3 & 11 \\
Hemşirelik Fakültesi & 6 & 1 & 5 & 6 & 10 & 28 \\
Hukuk Fakültesi & 24 & 17 & 14 & 38 & 1 & 94 \\
\hline İlahiyat Fakültesi & 61 & 13 & 19 & 29 & 10 & 132 \\
\hline İletişim Fakültesi & 12 & 7 & 10 & 13 & 14 & 56 \\
Mühendislik Fakültesi & 71 & 18 & 27 & 70 & 13 & 199 \\
Sağlık Bilimleri Fakültesi & 17 & 7 & 4 & 16 & 8 & 52 \\
\hline Siyasal Bilgiler Fakültesi & 50 & 20 & 24 & 29 & 10 & 133 \\
\hline Spor Bilimleri Fakültesi & 4 & 7 & 6 & 7 & 5 & 29 \\
\hline Tıp Fakültesi & 342 & 53 & 15 & 584 & 117 & 1.111 \\
\hline Uygulamalı Bilimler Fakültesi & 4 & 3 & 1 & 9 & 5 & 22 \\
\hline Veteriner Fakültesi & 78 & 11 & 6 & 49 & 3 & 147 \\
Ziraat Fakültesi & 127 & 15 & 7 & 50 & 13 & 212 \\
\hline \multicolumn{1}{c}{ Toplam } & 1.158 & 266 & 266 & 1.207 & 267 & 3.164 \\
\hline
\end{tabular}

Araştırmada kitleyi temsil kabiliyeti olan bir örneklem büyüklüğü belirlemek için Çıng1 (1990, s. 264) tarafından \%95 güven düzeyine karşılık gelen ve belirli özelliğe sahip kitle genişlikleri için önerilen örneklem miktarları kullanılmıştır. Bu kapsamda, araştırmaya konu 3.164 kişilik bir evren için Çıngı (1990) tarafından önerilen $\pm 0,03$ hata toleransı (hoşgörü miktarı) kullanıldığında 341 kişilik bir örneklem büyüklüğünün yeterli olacağı hesaplanmıştır. Tespit edilen örneklem sayısına ulaşabilmek için, deneklerden dönmeyecek anket miktarı ve geri dönen anketlerin bir kısmının da eksik doldurulabileceği göz önünde bulundurularak ihtiyat payı eklenmesi önerilmektedir (Çıngı, 1990; Gürbüz ve Şahin, 2018). Bu nedenle örneklemin yaklaşık \%5'i ilave edilerek $(341+19=360) 360$ kişilik bir örneklem büyüklügünün araştırma için yeterli olacağı hesaplanmıştır.

Söz konusu evrenden, olasılığa dayanan ve evreni temsil kabiliyeti diğer örnekleme tekniklerinden daha güçlü olan tabakalı (stratified) örnekleme tekniği kullanılarak örneklem seçilmiştir (Çıngı, 1990; Neuman, 2014). Tabakalı örneklem tekniğinde "araştırmanın sorunsalı üzerinde etkisi olması beklenen değişkenler açısından araştırma evreni kendi içerisinde türdeş olan alt gruplara (tabaka) ayrılır ve bu tabakalardan (evrendeki oranları nispetinde) rastgele 
seçimle örnekleme girecek birimler" (Gürbüz ve Şahin, 2018, s. 136) seçilmektedir. Bu kapsamda hem üniversitedeki fakültelerin (Tabaka-1), hem de her bir fakültedeki akademik personelin unvanları (Tabaka-2) tabaka grupları olarak belirlenmiştir. Örnekleme sürecinde tabakaların evren içindeki oranları dikkate alınarak her birim ve unvandan örnekleme dâhil edilecek sayılar belirlenmiştir. Daha sonra bu oranlara göre her tabakadan basit tesadüfî örneklem tekniğiyle tespit edilmiş olan akademik personel, araştırma örneklemine dâhil edilmiştir. Ancak, Güzel Sanatlar Fakültesinin akademik personel sayısı diğer fakültelere göre oldukça düşüktür. Bazı istatistiki analizlerin yapılabilmesi için her gruptan en az üç dönüt sayısına gereksinim duyulmaktadır. Bu nedenle söz konusu fakülteden üç akademik personel örnekleme dâhil edilecek şekilde örneklem sayısı iki artırılmıştır. Sonuç olarak 362 kişilik bir örneklem büyüklüğünün araştırma için yeterli olacağı hesaplanmış ve veri toplama işleminde bu sayıya ulaşılması hedeflenmiştir.

Araştırmaya katılan deneklerin birim ve unvanlarına göre dağılımlarının yer aldığı Tablo 2'deki bulgulardan anlaşılacağı üzere, örneklem belirleme sürecinde tespit edilen asgari örneklem büyüklüğünün $(\mathrm{N}=362)$ oldukça üzerinde bir örneklem sayısına $(\mathrm{N}=560)$ ulaşılmıştır. $\mathrm{Bu}$ nedenle elde edilen 560 kişilik bir örneklem büyüklügüünün araştırmanın evrenini oldukça yüksek düzeyde temsil ettiği ifade edilebilir.

\section{Tablo 2}

Birimler ve Akademik Personel İçin Belirlenen ve Gerçekleşen Örneklem Sayıları

\begin{tabular}{|c|c|c|c|c|c|c|c|c|c|c|c|c|c|c|}
\hline \multirow{3}{*}{ Fakülteler } & \multicolumn{10}{|c|}{ Unvan } & \multirow{2}{*}{\multicolumn{2}{|c|}{ Toplam }} & \multirow{3}{*}{ 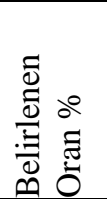 } & \multirow{3}{*}{ 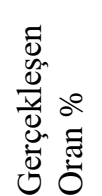 } \\
\hline & \multicolumn{2}{|c|}{ Prof.Dr. } & \multicolumn{2}{|c|}{ Doç.Dr. } & \multicolumn{2}{|c|}{$\begin{array}{c}\text { Dr.Öğr. } \\
\text { Üyesi }\end{array}$} & \multicolumn{2}{|c|}{ Arş.Gör. } & \multicolumn{2}{|c|}{ Öğr.Gör. } & & & & \\
\hline & BÖ & GÖ & BÖ & GÖ & BÖ & GÖ & BÖ & GÖ & BÖ & GÖ & BÖ & GÖ & & \\
\hline $\begin{array}{l}\text { Dil ve Tarih-Coğrafya } \\
\text { Fakültesi }\end{array}$ & 14 & 21 & 4 & 8 & 7 & 9 & 10 & 32 & 2 & 6 & 37 & 76 & 10,37 & 13,57 \\
\hline Diş Hekimliği Fakültesi & 7 & 7 & 1 & 1 & 0 & 0 & 11 & 11 & 1 & 1 & 20 & 20 & 5,44 & 3,57 \\
\hline Eczacılık Fakültesi & 5 & 5 & 1 & 4 & 2 & 2 & 5 & 10 & 1 & 1 & 14 & 22 & 3,79 & 3,93 \\
\hline Eğitim Bilimleri Fakültesi & 3 & 8 & 3 & 4 & 2 & 3 & 3 & 19 & 2 & 4 & 13 & 38 & 3,67 & 6,79 \\
\hline Fen Fakültesi & 10 & 10 & 3 & 4 & 3 & 3 & 5 & 8 & 2 & 2 & 23 & 27 & 6,38 & 4,82 \\
\hline Güzel Sanatlar Fakültesi & 0 & 2 & 0 & 0 & 1 & 1 & 1 & 6 & 1 & 4 & 3 & 13 & 0,35 & 2,32 \\
\hline Hemşirelik Fakültesi & 1 & 1 & 0 & 1 & 0 & 0 & 1 & 4 & 1 & 4 & 3 & 10 & 0,88 & 1,79 \\
\hline Hukuk Fakültesi & 3 & 3 & 2 & 3 & 2 & 2 & 4 & 6 & 0 & 2 & 11 & 16 & 2,97 & 2,86 \\
\hline İlahiyat Fakültesi & 7 & 9 & 2 & 2 & 2 & 3 & 3 & 6 & 1 & 2 & 15 & 22 & 4,17 & 3,93 \\
\hline İletişim Fakültesi & 1 & 1 & 1 & 1 & 1 & 1 & 1 & 3 & 2 & 2 & 6 & 8 & 1,77 & 1,43 \\
\hline Mühendislik Fakültesi & 8 & 8 & 2 & 3 & 3 & 3 & 8 & 15 & 2 & 4 & 23 & 33 & 6,29 & 5,89 \\
\hline Sağlık Bilimleri Fakültesi & 2 & 5 & 1 & 2 & 0 & 0 & 2 & 24 & 1 & 3 & 6 & 34 & 1,64 & 6,07 \\
\hline Siyasal Bilgiler Fakültesi & 6 & 6 & 2 & 3 & 3 & 4 & 3 & 8 & 1 & 4 & 15 & 25 & 4,20 & 4,46 \\
\hline Spor Bilimleri Fakültesi & 0 & 2 & 1 & 2 & 1 & 1 & 1 & 2 & 0 & 2 & 3 & 9 & 0,92 & 1,61 \\
\hline Tıp Fakültesi & 39 & 39 & 6 & 8 & 2 & 4 & 66 & 74 & 13 & 14 & 126 & 139 & 35,11 & 24,82 \\
\hline $\begin{array}{l}\text { Uygulamalı Bilimler } \\
\text { Fakültesi }\end{array}$ & 1 & 1 & 0 & 1 & 0 & 0 & 1 & 1 & 1 & 3 & 3 & 6 & 0,70 & 1,07 \\
\hline Veteriner Fakültesi & 9 & 9 & 1 & 1 & 1 & 1 & 6 & 11 & 0 & 1 & 17 & 23 & 4,65 & 4,11 \\
\hline Ziraat Fakültesi & 14 & 21 & 2 & 2 & 1 & 1 & 6 & 10 & 1 & 5 & 24 & 39 & 6,70 & 6,96 \\
\hline Toplam & 130 & 158 & 32 & 50 & 31 & 38 & 137 & 250 & 32 & 64 & 362 & 560 & 100,00 & 100,00 \\
\hline
\end{tabular}

Not: BÖ: Belirlenen örneklem sayıları; GÖ: Gerçekleşen örneklem sayıları. 


\section{Veri Toplama}

Araştırma kapsamında, anket uygulanmadan önce bir pilot çalışma gerçekleştirilmiştir. Pilot çalışma doktora düzeyinde eğitim almakta olan veya doktora eğitimini tamamlamış 36 araştırmacıya uygulanmıştır. Böylece araştırmanın hedef kitlesiyle benzer özelliklere sahip bir grup üzerinde ön uygulama yapılmıştır. Yapılan pilot uygulamayla gerçekleştirilecek anketin geçerlik ve güvenirliğinin gözleme dayalı verilerle sorgulanması sağlanmış ve elde edilen veriler üzerinden ön analizler ve testler uygulanmıştır.

Anket uygulamasına geçilmeden önce Ankara Üniversitesinden Etik Kurul izni alınmıştır. Anket, 25.10.2019-20.01.2020 tarihleri arasında gerçekleştirilmiştir. AÜ fakültelerinde görev yapan akademisyenlerden, Google Formlar aracılığıyla düzenlenmiş çevrim içi anket aracılığıyla veri toplanmıştır. Tabakalı örneklemdeki her bir tabakada ulaşılması gereken örneklem sayısını tamamlayabilmek için çevrim içi anket yoluyla yeterince dönüt alınamayan fakültelere gidilerek anketlerin doldurulması sağlanmıştır.

Veri toplama süreci sonunda toplam 582 akademisyenden geri bildirim alınmıştır. Analizlere başlamadan önce veri toplama süreci sonucunda elde edilen toplam 582 katılımciya ait veriler öncelikle eksik veri ve aykırı gözlem değerleri (uç veri) bakımından incelenmiştir. İnceleme sonucunda birimini belirtmeyen ve değerlendirilemeyecek oranda eksik veri içeren toplam 22 adet anket yanıtının veri setinden çıkarılmasına karar verilmiştir (Hair, Black, Babin ve Anderson, 2014). Dolayısıyla araştırmanın analizleri, 560 katılımcıdan elde edilen veriler üzerinden gerçekleştirilmiştir.

\section{Veri Analizi, Geçerlik ve Güvenilirlik}

Araştırmanın verileri IBM SPSS paket programı 25. sürümü kullanılarak analiz edilmiştir. Çalışmada boyutların ikili grup karşılaştırmalarında (cinsiyet), bağımsız grup t-testi analizi uygulanmıştır. Üç veya daha fazla grup karşılaştırmaları (yaş, unvan ve akademik birim) için ise tek yönlü varyans analizi (ANOVA) kullanılmıştır. ANOVA testinden önce önkoşul olan varyansın homojen olduğu varsayımı (homogeneity of variance) Levene testi ile test edilmiştir. ANOVA sonuçları anlamlı bulunan farklılıkların kaynağını belirlemek üzere çoklu karşılaştırma analizi, Post Hoc testlerinden Tukey testi kullanılmıştır. Değişkenler arasındaki ilişkileri belirlemek amacıyla Pearson Korelasyon analizi yapılmıştır. Açık uçlu ve birden fazla seçeneğin işaretlenebildiği sorularda ise içerik analizi ile analiz yapılarak sıklık frekansları oluşturulmuştur.

Araştırmada kullanılan Likert ölçeği ile hazırlanmış soruların içsel tutarlılık cinsinden Cronbach alfa güvenilirlik değerleri hesaplanmıştır. Buna göre; ASA'ların kullanım zorluğuna ilişkin 9 maddelik ölçeğin Cronbach alfa katsayı değerinin 0,90 olduğu tespit edilmiştir. ASA'lara ilişkin 7 maddelik tutum ölçeğinin Cronbach alfa katsayı değerinin 0,74 olduğu saptanmıştır. Son olarak ASA'lara ilişkin eğitim gereksinimini tespit etmek amaciyla hazırlanan 3 maddelik ölçeğin Cronbach alfa katsayı değerinin 0,94 olduğu tespit edilmiştir. Elde edilen katsayı değerleri, literatürde eşik değer olarak yaygın kabul gören 0.70 'in üstünde değerler olduğundan (Gürbüz ve Şahin, 2018), araştırmada kullanılan Likert ölçekli soruların güvenilir ölçekler olduğunu göstermektedir. Ayrıca ASA'lara ilişkin tutum ölçeği değerlendirilirken olumsuz ifadeler için tersine kodlama yapılmıştır. 


\section{Bulgular ve Değerlendirme}

Anket uygulamasına ilişkin elde edilen bulgular demografik bilgiler, SA ve ASA kullanımı, SA ve ASA kullanım amaçları ile kullanılmama nedenleri, ASA kullanımında karşılaşılan zorluklar, ASA'ların sunduğu göstergelerin akademisyenler açısından önemi ile ASA ve eğitim gereksinimi alt başlıkları şeklinde sunulmaktadır.

\section{Demografik Bilgiler}

Araştırmaya katılan deneklerin demografik özelliklerine yönelik bilgiler Tablo 3 'te verilmiştir. Akademisyenlerin \%87,3'ünün SA hesaplarına sahip olduğu, benzer şekilde \%82,7'sinin ASA'ları kullandığı tespit edilmiştir. Hem SA'ları hem de ASA'ları kullanan akademisyen say1s1 410'dur. SA ve ASA'ların her ikisini de kullanmayan akademisyen sayısı yalnızca 18'dir. Bu bulgular akademisyenlerin büyük çoğunluğunun SA'ları ve ASA'ları kullandıklarına işaret etmektedir.

\section{Tablo 3}

Akademisyenlerin Demografik Özellikleri

\begin{tabular}{|c|c|c|c|}
\hline Değişken & Özellik & $\mathrm{N}$ & Yüzde (\%) \\
\hline \multirow{2}{*}{ Cinsiyet } & Kadin & 325 & 58,0 \\
\hline & Erkek & 235 & 42,0 \\
\hline \multirow{5}{*}{ Yaş dağılımları } & 20-29 yaş & 99 & 17,7 \\
\hline & 30-35 yaş & 162 & 28,9 \\
\hline & $36-40$ yaş & 68 & 12,1 \\
\hline & $41-50$ yaş & 95 & 17,0 \\
\hline & 51 ve üzeri yaş & 136 & 24,3 \\
\hline \multirow{5}{*}{ Unvan dağılımları } & Prof.Dr. & 158 & 28,2 \\
\hline & Doç.Dr. & 50 & 8,9 \\
\hline & Dr.Öğr.Üyesi & 38 & 6,8 \\
\hline & Öğr.Gör. & 64 & 11,4 \\
\hline & Arş.Gör. & 250 & 44,6 \\
\hline \multirow{2}{*}{ SA hesap sahipliği } & Evet & 489 & 87,3 \\
\hline & Hayır & 71 & 12,7 \\
\hline \multirow{2}{*}{$\begin{array}{l}\text { ASA kullanım } \\
\text { durumu }\end{array}$} & Evet & 463 & 82,7 \\
\hline & Hayır & 97 & 17,3 \\
\hline
\end{tabular}

\section{SA ve ASA Kullanımı}

\section{Akademisyenlerin $S A$ ve ASA kullanma süreleri}

Akademisyenlerin SA ve ASA kullanım sürelerine ilişkin bilgiler Tablo 4'te verilmiştir. Akademisyenlerin \%12,9'u 1-5 y1l, \%36,6's1 6-10 yı1, \%37,7'si 11 y1l ve daha fazla sürelerle SA'ları kullandıkları tespit edilmiştir. Akademisyenlerin \%3,4'ü 1 yıldan az, \%22,5'i 1-3 yıl 
arası, \%31,1'i 4-5 yıl arası ve \%25,7'si ise 6-10 y1l arası sürelerle ASA'ları kullandıklarını bildirmişlerdir.

\section{Tablo 4}

Akademisyenlerin SA ve ASA Kullanım Süreleri

\begin{tabular}{cccc}
\hline Değişkenler & Süreler & Sıklık & Yüzde (\%) \\
\hline \multirow{2}{*}{ SA kullanım süresi } & $1-5$ yıl & 72 & 12,9 \\
& 6-10 yıl & 205 & 36,6 \\
& 11 yıl ve daha fazla & 211 & 37,7 \\
\hline \multirow{2}{*}{ ASA kullanım süresi } & 1 y1ldan az & 19 & 3,4 \\
& $1-3$ yıl & 126 & 22,5 \\
& $4-5$ yıl & 174 & 31,1 \\
& $6-10$ yıl arası & 144 & 25,7 \\
\hline
\end{tabular}

SA kullanım süresi ile ASA kullanım süresi arasındaki ilişki

Akademisyenlerin SA kullanım süresi ile ASA kullanım süresi arasında anlamlı bir ilişki olup olmadığını test etmek amacıyla Pearson korelasyon analizi yapılmıştır. Korelasyon analizi bulgularına (Tablo 5) göre, akademisyenlerin SA kullanım süresi ile ASA kullanım süresi arasında olumlu yönde anlamlı bir korelasyon olduğu saptanmıştır $(r=0,22, p<0,01)$. Bu bulgu katılımcıların SA kullanım süresi ile ASA kullanım süresinin birlikte arttığı ya da azaldığ1 anlamına gelmektedir.

\section{Tablo 5}

SA Kullanım Süresi ile ASA Kullanım Süresi Arasındaki Illişki

\begin{tabular}{lccc}
\hline \multicolumn{1}{c}{ Değişkenler } & Ort. & SS & 1 \\
\hline 1. SA kullanım süresi & 2,28 &, 707 & - \\
2. ASA kullanım süresi & 2,96 &, 864 &, $222^{* *}$ \\
\hline
\end{tabular}

Not: **0,01 düzeyinde anlamlı (2-tailed)

\section{Akademisyenlerin ASA kullanım süresi ile kullanım sıklıkları arasındaki ilişki}

Akademisyenlerin ASA'ları kullanım süresi ile kullanım sıklıkları arasında anlamlı bir ilişki olup olmadığını test etmek amacıyla yapılan Pearson korelasyon analizi sonuçlarına (Tablo 6) göre, ASA'ları kullanım süresi ile ResearchGate ( $\mathrm{r}=0,15, \mathrm{p}<0,01)$, Academia.edu ( $\mathrm{r}=0,17$; $\mathrm{p}<0,05)$ ve LinkedIn $(\mathrm{r}=0,13, \mathrm{p}<0,05)$ ağlarını kullanma sıklıkları arasında olumlu yönde anlamlı korelasyon tespit edilmiştir. Bu bulgu, akademisyenlerin ASA'ları kullanım süreleri arttıkça ResearchGate, Academia.edu ve LinkedIn ağlarını kullanım sıklığına dair tutum puanlarının da arttığına işaret etmektedir.

Tablo 6'dan izleneceği üzere; AÜ akademisyenleri tarafindan en çok tercih edilen ASA'lar sirasiyla Google Scholar (Ort. 3,74), ResearchGate (Ort. 3,61) ve Academia.edu (Ort. 3,18 ) olarak tespit edilmiştir. 


\section{Tablo 6}

ASA Kullanım Süresi ve ASA Kullanma Siklıkları Arasındaki İlişki

\begin{tabular}{|c|c|c|c|c|c|c|c|c|c|c|c|c|}
\hline Değişkenler & Ort. & SS & 1 & 2 & 3 & 4 & 5 & 6 & 7 & 8 & 9 & 10 \\
\hline $\begin{array}{l}\text { 1. ASA kullanım } \\
\text { süresi }\end{array}$ & 2,96 & 0,86 & & & & & & & & & & \\
\hline 2. ResearchGate & 3,61 & 1,08 &, $154^{* *}$ & & & & & & & & & \\
\hline 3. Academia.edu & 3,18 & 1,18 &, $174^{* *}$ &, $451^{* *}$ & & & & & & & & \\
\hline 4. Google Scholar & 3,74 & 1,15 & ,067 &, $542^{* *}$ &, $415^{* *}$ & & & & & & & \\
\hline 5. Mendeley & 2,78 & 1,30 & ,048 &, $304^{* *}$ &, $329^{* *}$ &, $265^{* *}$ & & & & & & \\
\hline 6. Impactstory & 1,72 & 0,74 & 065 & 0,07 & 0,22 & 0,13 &, $295^{*}$ & & & & & \\
\hline 7. Epernicus & 1,63 & 0,72 & 079 & 0,00 & 0,15 & 0,09 & 0,14 &, $896^{* *}$ & & & & \\
\hline 8.ScienceStagecom & 1,91 & 1,00 &, 009 & 0,05 & 0,19 & 0,17 &, $449^{* * *}$ &, $632^{* *}$ & $716^{* *}$ & & & \\
\hline 9. LinkedIn & 2,97 & 1,30 &, $127^{*}$ &, $380^{* *}$ &, $302^{* *}$ &, $316^{* *}$ &, $286^{* *}$ &, $371^{* *}$ & $298^{*}$ & 0,13 & & \\
\hline 10. Kudos & 1,63 & 0,85 &,- 122 & 0,07 & 0,23 & 0,14 & 0,28 &, $710^{* *}$ & $721^{* *}$ & $504^{* *}$ & 0,28 & \\
\hline 11. Edmodo & 1,86 & 1,07 &,- 059 &,$- 313^{*}$ & $-0,06$ &,$- 272^{*}$ & 0,06 &, $520^{* *}$ & $508^{* *}$ & 0,25 & 0,20 &, $527^{* *}$ \\
\hline
\end{tabular}

Not: ** 0,01 düzeyinde anlamlı (2-tailed); * 0,05 düzeyinde anlamlı.

Akademisyenlerin SA ve ASA kullanım durumlarının fakültelere göre karşılaştırılması

Akademisyenlerin SA'ları kullanım durumlarının fakültelerine göre anlamlı düzeyde farklılaşıp farklılaşmadığını tespit etmek amacıyla ANOVA testi uygulanmıştır. Akademisyenlerin fakültelerine göre yapılan ANOVA testi sonuçlarına göre, akademisyenlerin SA'ları kullanım durumlarının fakültelerine göre anlamlı düzeyde farklılaşmadığı tespit edilmiştir ( $\mathrm{F}=903$; $\mathrm{p}=0,570$ ). Başka bir anlatımla, akademisyenlerin SA kullanım tercihleri fakülteleri bakımından büyük ölçüde benzerlik göstermektedir.

Akademisyenlerin ASA'ları kullanım durumlarının fakültelerine göre anlamlı düzeyde farklılaşıp farklılaşmadığına bakıldığında, fakültelere göre yapılan ANOVA testi sonuçlarına (Tablo 7) göre, akademisyenlerin ASA'ları kullanım durumlarının fakültelerine göre anlamlı düzeyde farklılaştığı tespit edilmiştir $(F=3,275 ; \mathrm{p}<0,05)$. Farklılığın hangi fakültelerden kaynaklandığını saptamak amacıyla Tukey testi yapılmıştır. Tukey testi sonuçlarına göre, Tıp Fakültesindeki akademisyenlerin (Ort.=1,31) ASA kullanım sıklıklarının, Dil ve TarihCoğrafya Fakültesi (Ort.=1,08) ve Eğitim Bilimleri Fakültesindeki akademisyenlerin kullanım sıklıklarından (Ort.=1,03) daha düşük olduğu ve bu farklılığın anlamlı olduğu görülmektedir. $\mathrm{Bu}$ bulgudan yola çıkarak Tıp Fakültesindeki akademisyenlerin, Dil ve Tarih-Coğrafya Fakültesi ve Eğitim Bilimleri Fakültesindeki akademisyenlere göre ASA'ları daha az kullandığ ifade edilebilir. Benzer şekilde, Diş Hekimliği Fakültesindeki akademisyenlerin $($ Ort. $=1,40)$ ASA kullanım durumları, Eğitim Bilimleri Fakültesindeki akademisyenlerin kullanım durumlarına göre (Ort.=1,03) daha düşük olduğu ve bu farklılığın anlamlı olduğu görülmektedir. Bu bulgudan yola çıkarak Diş Hekimliği Fakültesindeki akademisyenlerin, Eğitim Bilimleri Fakültesindeki akademisyenlere göre ASA'ları daha az kullandığı ifade edilebilir. 
Tablo 7

Fakültelere göre ASA Kullanımı

\begin{tabular}{|c|c|c|c|c|c|c|}
\hline Boyutlar & Fakülteler & $\mathrm{N}$ & Ort. & SS & $\mathrm{F}$ & $\mathrm{p}$ \\
\hline \multirow{18}{*}{ ASA Kullanımı } & $\begin{array}{l}\text { Dil ve Tarih-Coğrafya } \\
\text { Fakültesi }\end{array}$ & 76 & 1,08 & ,271 & \multirow{18}{*}{3,275} & \multirow{18}{*}{, 000} \\
\hline & Diş Hekimliği Fakültesi & 20 & 1,40 &, 503 & & \\
\hline & Eczacılık Fakültesi & 22 & 1,05 & ,213 & & \\
\hline & Eğitim Bilimleri Fakültesi & 38 & 1,03 & ,162 & & \\
\hline & Fen Fakültesi & 27 & 1,15 &, 362 & & \\
\hline & Güzel Sanatlar Fakültesi & 13 & 1,15 & ,376 & & \\
\hline & Hemşirelik Fakültesi & 10 & 1,40 &, 516 & & \\
\hline & Hukuk Fakültesi & 16 & 1,25 & ,447 & & \\
\hline & İlahiyat Fakültesi & 22 & 1,05 & ,213 & & \\
\hline & İletişim Fakültesi & 8 & 1,25 & ,463 & & \\
\hline & Mühendislik Fakültesi & 33 & 1,15 & ,364 & & \\
\hline & Sağlık Bilimleri Fakültesi & 34 & 1,12 &, 327 & & \\
\hline & Siyasal Bilgiler Fakültesi & 25 & 1,04 & ,200 & & \\
\hline & Spor Bilimleri Fakültesi & 9 & 1,22 &, 441 & & \\
\hline & Tip Fakültesi & 139 & 1,31 & ,464 & & \\
\hline & $\begin{array}{l}\text { Uygulamalı Bilimler } \\
\text { Fakültesi }\end{array}$ & 6 & 1,17 & ,408 & & \\
\hline & Veteriner Fakültesi & 23 & 1,04 & 209 & & \\
\hline & Ziraat Fakültesi & 39 & 1,18 & ,389 & & \\
\hline
\end{tabular}

Akademisyenlerin SA kullanım durumlarının cinsiyet, yaş ve unvan değişkenlerine göre gösterdiği farklılık

Akademisyenlerin SA'ları kullanım durumlarının cinsiyetlerine göre anlamlı düzeyde farklılaşıp farklılaşmadığını tespit etmek amacıyla bağımsız gruplar arası $\mathrm{t}$ testi (independent samples t test) uygulanmıştır. Sonuçlara göre, akademisyenlerin SA kullanım durumları cinsiyetlerine göre anlamlı düzeyde farklılaşmamaktadır $(\mathrm{p}>0,05)$.

Akademisyenlerin SA'ları kullanım durumlarının yaş gruplarına göre anlamlı düzeyde farklılaşıp farklılaşmadığını tespit etmek amacıyla ANOVA testi uygulanmıştır. Akademisyenlerin yaş gruplarına göre yapılan ANOVA testi sonuçlarına (Tablo 8) göre, akademisyenlerin SA'ları kullanım durumlarının yaş gruplarına göre anlamlı düzeyde farklılaştığı tespit edilmiştir $(\mathrm{F}=5,137 ; \mathrm{p}<0,05)$. Farklılı̆̆ın hangi yaş grubundan kaynaklandığını saptamak amacıyla Tukey testi yapılmıştır. Tukey testi sonuçlarına göre, 51 ve üzeri yaş grubundaki akademisyenlerin diğer yaş gruplarındaki akademisyenlere göre SA 
kullanım durumlarının (Ort.=1,22) daha düşük olduğu ve bu farklılığın anlamlı olduğu görülmektedir. Bu bulgudan yola çıkarak 51 ve üzeri yaş grubundaki akademisyenlerin SA'ları daha az kullandığı ifade edilebilir.

\section{Tablo 8}

Yaş Gruplarına göre SA Kullanımı

\begin{tabular}{ccccccc}
\hline Boyutlar & Yaş & N & Ortalama & SS & F & p \\
& 20-29 yaş & 99 & 1,08 &, 274 & & \\
& 30-35 yaş & 162 & 1,07 &, 263 & & \\
SA & $36-40$ yaş & 68 & 1,07 &, 263 & 5,137 &, 000 \\
Kullanımı & 41-50 yaş & 95 & 1,17 &, 376 & & \\
& 51 ve üzeri yaş & 136 & 1,22 &, 416 & & \\
\hline
\end{tabular}

Akademisyenlerin SA'ları kullanım durumlarının unvanlarına göre anlamlı düzeyde farklılaştığı tespit edilmiştir $(\mathrm{F}=4.096 ; \mathrm{p}<0,05)$. Farklılığın hangi unvandan kaynaklandığını saptamak amacıyla Tukey testi yapılmıştır (Tablo 9). Tukey testi sonuçlarına göre, Prof. Dr. unvanına sahip akademisyenlerin Öğr. Gör ve Arş. Gör. unvanına sahip akademisyenlere göre SA kullanım durumlarının (Ort.=1,21) daha düşük olduğu ve bu farklılığın anlamlı olduğu görülmektedir. $\mathrm{Bu}$ bulgudan yola çıkarak Öğr. Gör. ve Arş. Gör. unvanına sahip akademisyenlerin SA'ları Prof. Dr. unvanına sahip akademisyenlere göre daha fazla kullandığ ifade edilebilir.

\section{Tablo 9}

Unvanlara göre SA Kullanımı

\begin{tabular}{ccccccc}
\hline Boyutlar & Unvan & N & Ortalama & SS & F & p \\
& Prof.Dr. & 158 & 1,21 &, 408 & & \\
& Doç.Dr. & 50 & 1,16 &, 370 & & \\
SA & Dr.Öğr.Üyesi & 38 & 1,11 &, 311 & 4,096 &, 003 \\
Kullanımı & Arş.Gör. & 250 & 1,09 &, 284 & & \\
& Öğr.Gör. & 64 & 1,06 &, 244 & & \\
\hline
\end{tabular}

Akademisyenlerin ASA kullanım durumlarının cinsiyet, yaş ve unvan değişkenlerine göre gösterdiği farklılık

Akademisyenlerin ASA'ları kullanım durumlarının cinsiyetlerine göre anlamlı düzeyde farklılaşıp farklılaşmadığını tespit etmek amacıyla bağımsız gruplar arası t testi (independent samples t test) uygulanmıştır. Sonuçlara göre, akademisyenlerin ASA kullanım durumları, cinsiyetlerine göre anlamlı düzeyde farklılaşmamaktadır $(\mathrm{p}>0,05)$.

Akademisyenlerin ASA'ları kullanım durumlarının yaş gruplarına göre anlamlı düzeyde farklılaştığı tespit edilmiş olup $(\mathrm{F}=4,155 ; \mathrm{p}<0,05)$, farklılı̆̆ın hangi yaş grubundan 
kaynaklandığını saptamak amacıyla Tukey testi yapılmıştır (Tablo 10). Tukey testi sonuçlarına göre, 20-29 yaş grubundaki akademisyenlerin, 30-35 ve 36-40 yaş gruplarındaki akademisyenlere göre ASA kullanım durumlarının (Ort.=1,28) daha düşük olduğu ve bu farklılığın anlamlı olduğu görülmektedir. Bu bulgudan yola çıkarak 20-29 yaş grubundaki akademisyenlerin, 30-35 ve 36-40 yaş grubundaki akademisyenlere göre ASA'ları daha az kullandığı ifade edilebilir. Ayrıca 51 ve üzeri yaş grubundaki akademisyenlere 1,21 ortalama ile 20-29 yaş grubunu takip etmektedir. Ancak 51 ve üzeri yaş grubunun ortalaması anlamlı düzeyde diğer gruplardan farklılaşmamaktadır.

\section{Tablo 10}

Yaş Gruplarına göre ASA Kullanımı

\begin{tabular}{ccccccc}
\hline Boyutlar & Yaş & N & Ortalama & SS & F & p \\
& 20-29 yaş & 99 & 1,28 &, 453 & & \\
& $30-35$ yaş & 162 & 1,13 &, 337 & & \\
ASA & $36-40$ yaş & 68 & 1,09 &, 286 & 4,155 &, 003 \\
Kullanımı & 41-50 yaş & 95 & 1,14 &, 346 & & \\
& 51 ve üzeri yaş & 136 & 1,21 &, 411 & & \\
\hline
\end{tabular}

Akademisyenlerin ASA'ları kullanım durumlarının unvanlarına göre anlamlı düzeyde farklılaşıp farklılaşmadığını tespit etmek amacıyla yapılan ANOVA testi sonuçlarına (Tablo 11) göre, akademisyenlerin ASA'ları kullanım durumlarının unvanlarına göre anlamlı düzeyde farklılaşmadığ 1 tespit edilmiştir $(\mathrm{F}=223 ; \mathrm{p}=.926)$. Başka bir anlatımla akademisyenlerin ASA kullanım tercihleri unvanları bakımından büyük ölçüde benzerlik göstermektedir. ASA kullanımlarında yaşlara göre anlamlı fark bulunurken unvanlara göre bulunmamaktadır. Unvanlara göre ortalamalar Tablo 11'de görüldüğü gibi 1,13 ile 1,19 arasında değişmektedir, dolayısıyla varyasyon düşüktür. Yaştaki varyasyon daha fazla olduğu için Tukey testine göre yaşta anlamlı farklılık gözükmektedir.

\section{Tablo 11}

Unvanlara göre ASA Kullanımı

\begin{tabular}{ccccccc}
\hline Boyutlar & Unvan & N & Ortalama & SS & F & p \\
& Prof.Dr. & 132 & 1,16 &, 372 & & \\
& Doç.Dr. & 42 & 1,16 &, 370 & & \\
$\begin{array}{c}\text { ASA } \\
\text { Kullanımı }\end{array}$ & Dr.Öğr.Üyesi & 33 & 1,13 &, 343 & 223 &, 926 \\
& Arş.Gör. & 204 & 1,18 &, 388 & & \\
& Öğr.Gör. & 52 & 1,19 &, 393 & & \\
\hline
\end{tabular}




\section{SA ve ASA Kullanım Amaçları ile Kullanılmama Nedenleri}

Akademisyenlerin SA 'ları ve ASA'ları kullanım amaçları

Akademisyenlerin SA'ları en çok bilgi edinmek (Sıklık=426), Aile ve arkadaşlarla iletişim halinde olmak $($ Sıklık=325), Akademik çalışma ve etkinlikleri duyurmak ve paylaşmak (Sıklık=274), Paylaşımda bulunmak (video, fotoğraf, müzik vs.) (Sıklık=255), Mesleki ve ticari olarak iletişim kurmak (Sıklık=221) amaçları için kullandıkları tespit edilmiştir.

Akademisyenlerin ASA'ları kullanım amaçlarına ilişkin frekans (sıklık) tablosu Tablo 12'de sunulmuştur. Akademisyenlerin ASA'ları en çok alanıyla ilgili yayınları takip etmek $($ Sıklık=426), alanıyla ilgili yenilikleri takip etmek $(S ı k l 1 k=349)$ ve akademik çalışmaları paylaşmak (Sıklık=340) amaçları için kullandıkları görülmektedir.

\section{Tablo 12}

Akademisyenlerin ASA Kullanım Amaçları

\begin{tabular}{lc}
\multicolumn{1}{c}{ Amaç } & Sıklık \\
\hline 1. Alanımla ilgili yayınları takip etmek & 426 \\
2. Alanımla ilgili yenilikleri takip etmek & 349 \\
3. Akademik çalışmalarımı paylaşmak & 340 \\
4. Kendi çalışmalarıma ait atıf ve takipçi sayılarını görmek & 273 \\
5. Belirli kişi ya da grupları takip etmek & 203 \\
6. İşbirliği yapabileceğim kişileri belirlemek & 193 \\
7. Yayınlarımı yükleyebileceğim bir platform olarak (depo) & 148 \\
8. Tarafıma gelen yayın isteklerini göndermek & 138 \\
9. Belirli konu, çalışma, proje vb. etkinliklerle ilgili sorulara katkı vermek, görüş alış & 131 \\
verişinde bulunmak & 130 \\
10. Referans yönetim aracı olarak & 94 \\
11. Diğer araştırmacıların atıf ve takipçi sayılarını görmek & 65 \\
12. Çalışmasına atıfta bulunduğum diğer araştırmacıların almış olduğu atıflara bakmak & 45 \\
13. Diğer araştırmacılara yayın önermek & \\
\hline
\end{tabular}

\section{SA ve ASA kullanmayan akademisyenlerin her iki ă̆ da kullanmama nedenleri}

Akademisyenlerin SA'ları kullanmama nedenlerinin başında sırasıyla çok fazla zamanımı alacağını düşünüyorum (S1klık=52) ve SA'lara katılmaya ilgi duymuyorum (S1klık=36) maddeleri gelmektedir. Akademisyenlerin ASA'ları kullanmama nedenlerinin başında ise sırasıyla ASA'lar hakkında bilgim yok (Sıklık=50), ASA'ları kullanmam için bir zorunluluk bulunmuyor (Sıklık=22) ile ASA'lara hiçbir şekilde yönlendirilmedim $\left(S_{1 k} 1\right.$ k $\left.=22\right)$ maddeleri gelmektedir.

\section{ASA Kullanımında Karşılaşılan Zorluklar}

\section{Akademisyenlerin ASA'ları kullanma zorluğuna ilişkin tutumları}

Akademisyenlerin ASA'ları kullanma zorluğuna ilişkin tutum puan ortalamaları Tablo 13'te yer almaktadır. Buna göre, en fazla Düzenli kullanım sağlamada zorlanıyorum (Ort. $=2,30)$, ASA'lardan gelen bildirimleri takip etmede zorlanıyorum (Ort. $=2,27)$ ve Tarafıma gelen yayın isteklerini karşılamada zorlanıyorum (Ort.=2,08) maddelerine yönelik zorlanma söz konusudur. 
Tablo 13

ASA Kullanımında Zorlanma Düzeyleri

\begin{tabular}{lcc}
\hline \multicolumn{1}{c}{ Maddeler (... zorlanıyorum) } & Ort. & SS \\
\hline ASA platformlarının İngilizce olmasında & 1,77 &, 882 \\
Profil oluşturmada & 1,78 &, 861 \\
Yayınlarımı yüklemede & 1,80 &, 863 \\
Üyelik bilgilerimi güncellemede & 1,73 &, 832 \\
Yayın ve araştırma verilerimi güncellemede & 1,84 &, 911 \\
Düzenli kullanım sağlamada & 2,30 & 1,117 \\
Yayınlara erişim sağlamada & 2,01 &, 982 \\
Tarafıma gelen yayın isteklerini karşılamada & 2,08 & 1,019 \\
ASA'lardan gelen bildirimleri takip etmede & 2,27 & 1,130 \\
Tüm maddeler ortalama & 1,9537 &, 71421 \\
\hline
\end{tabular}

Akademisyenlerin ASA'ları kullanma zorluğuna ilişkin tutumlarının unvan değişkenine göre gösterdiği farklılık

Akademisyenlerin ASA'ları kullanma zorluğuna ilişkin tutumlarının unvanlarına göre anlamlı düzeyde farklılaşıp farklılaşmadığını tespit etmek amacıyla ANOVA testi uygulanmıştır. ANOVA testi sonuçlarına (Tablo 14) göre, akademisyenlerin ASA kullanımında zorlanma düzeylerine ait ortalamanın, unvanlarına göre anlamlı düzeyde farklılaştı̆ğ tespit edilmiştir $(\mathrm{F}=2,807 ; \mathrm{p}<0,05)$. Tukey testi sonuçlarına göre; Prof. Dr. unvanına sahip akademisyenlerin ortalama puanının (Ort.=2,08), Dr. Öğr. Üyesi unvanına sahip akademisyenlere göre (Ort.= 1,67) daha yüksek olduğu ve bu farklılığın anlamlı olduğu görülmektedir. Bu bulgudan yola çıkarak Prof. Dr. unvanına sahip akademisyenlerin, ASA'ları kullanırken Dr. Öğr. Üyesi unvanına sahip akademisyenlere göre daha fazla zorlandı $\breve{g}$ ifade edilebilir.

\section{Tablo 14}

Unvanlara göre ASA Kullanımında Zorlanma Düzeyi

\begin{tabular}{ccccccc}
\hline Boyutlar & Unvan & N & Ortalama & SS & F & p \\
& Prof.Dr. & 132 & 2,08 & 0,77 & & \\
& Doç.Dr. & 42 & 1,81 & 0,75 & & \\
ASA & Dr.Öğr.Üyesi & 33 & 1,67 & 0,68 & 2,807 &, 025 \\
Kullanımı & Arş.Gör. & 204 & 1,94 & 0,67 & & \\
& Öğr.Gör. & 52 & 2,00 & 0,69 & & \\
\hline
\end{tabular}

\section{ASA'ların Sunduğu Göstergelerin Akademisyenler Açısından Önemi}

Akademisyenler altmetrik göstergelerden okunma sayısı $(\mathrm{S} 1 \mathrm{kl} 1 \mathrm{k}=188)$ ve indirilme sayılarını (S1klık=176) 5 ile derecelendirerek önemli bulduklarını belirtmişlerdir. Ancak geleneksel göstergelerden atıf sayıları (Sıklık=227) akademisyenler için önem derecesi en yüksek gösterge olarak tespit edilmiştir (Tablo 15). 
Tablo 15

ASA Göstergelerinin Önem Sirası

\begin{tabular}{|c|c|c|c|c|c|c|}
\hline \multirow[b]{2}{*}{ Göstergeler } & \multicolumn{6}{|c|}{ Önem derecesi (1= En Önemsiz, 5= En Önemli) } \\
\hline & 1 & 2 & 3 & 4 & 5 & $\mathrm{~N}$ \\
\hline Yayın sayısı & 43 & 59 & 133 & 174 & 151 & 560 \\
\hline İşbirliği sayısı & 37 & 72 & 166 & 181 & 104 & 560 \\
\hline Atıf sayısı & 32 & 37 & 88 & 176 & 227 & 560 \\
\hline Takip edilenlerin sayısı & 105 & 148 & 178 & 83 & 46 & 560 \\
\hline Takip edenlerin sayısı & 92 & 116 & 166 & 123 & 63 & 560 \\
\hline Yayınların okunma sayısı & 28 & 47 & 105 & 192 & 188 & 560 \\
\hline Yayınların indirilme sayısı & 37 & 53 & 98 & 196 & 176 & 560 \\
\hline Yazar profilinin görüntülenme sayısı & 72 & 113 & 185 & 128 & 62 & 560 \\
\hline $\begin{array}{l}\text { Sosyal medyada paylaşım ve bahsedilme } \\
\text { sayısı }\end{array}$ & 97 & 112 & 165 & 120 & 66 & 560 \\
\hline
\end{tabular}

\section{ASA ve Ĕgitim Gereksinimi}

\section{ASA'lara ilişkin ĕgitim gereksinimi}

Akademisyenlerin ASA'lara ilişkin eğitim gereksinimi ile ilgili verilen üç ifadeye katılım durumları Tablo 16'da yer almaktadır. Buna göre, “ASA'ların tanıtılacağı ve kullanımına ilişkin bilgilerin verileceği bir eğitim düzenlenmesini isterim" ifadesine, akademisyenlerin \%54,7'sinin (Katılıyorum=38,8 ve Kesinlikle katılıyorum=15,9) katıldığ1 görülmektedir. "ASA'ların tanıtılması ve kullanımına ilişkin bir eğitim düzenlenirse katılmak isterim" ifadesine \%53,7'si katıldığını bildirmektedir. “ASA'ların tanıtıldığı ve kullanımına ilişkin bilgilerin verildiği bir eğitim materyalinin hazırlanmasını isterim” ifadesine ise akademisyenlerin \%61,1'i katılmaktadır.

Tablo 16

ASA Ĕgitim Gereksinimi

\begin{tabular}{|c|c|c|c|c|c|c|c|c|c|c|c|c|}
\hline \multirow[t]{2}{*}{ Eğitim Gereksinimi } & \multicolumn{2}{|c|}{$\begin{array}{l}\text { Kesinlikle } \\
\text { Katılmiyorum }\end{array}$} & \multicolumn{2}{|c|}{ Katılmiyorum } & \multicolumn{2}{|c|}{$\begin{array}{l}\mathrm{Ne} \\
\text { kat1liyorum } \\
\text { ne } \\
\text { katılmiyorum }\end{array}$} & \multicolumn{2}{|c|}{ Katıliyorum } & \multicolumn{2}{|c|}{$\begin{array}{l}\text { Kesinlikle } \\
\text { katılıyorum }\end{array}$} & \multicolumn{2}{|c|}{ Toplam } \\
\hline & $\mathbf{N}$ & $\%$ & $\mathbf{N}$ & $\%$ & $\mathbf{N}$ & $\%$ & $\mathbf{N}$ & $\%$ & $\mathbf{N}$ & $\%$ & $\mathbf{N}$ & $\%$ \\
\hline $\begin{array}{l}\text { ASA'ların tanıtılacağ1 } \\
\text { ve kullanımına ilişkin } \\
\text { bilgilerin verileceği } \\
\text { bir eğitim } \\
\text { düzenlenmesini } \\
\text { isterim. }\end{array}$ & 43 & 7,7 & 69 & 12,3 & 142 & 25,4 & 217 & 38,8 & 89 & 15,9 & 560 & 100,1 \\
\hline $\begin{array}{l}\text { ASA'ların tanıtılması } \\
\text { ve kullanımına ilişkin } \\
\text { bir eğitim } \\
\text { düzenlenirse katılmak } \\
\text { isterim. }\end{array}$ & 53 & 9,5 & 77 & 13,8 & 129 & 23,0 & 214 & 38,2 & 87 & 15,5 & 560 & 100,0 \\
\hline $\begin{array}{l}\text { ASA'ların tanıtıldığı } \\
\text { ve kullanımına ilişkin } \\
\text { bilgilerin verildiği bir } \\
\text { eğitim materyalinin } \\
\text { hazırlanmasını } \\
\text { isterim. }\end{array}$ & 44 & 7,9 & 59 & 10,5 & 115 & 20,5 & 240 & 42,9 & 102 & 18,2 & 560 & 100,1 \\
\hline
\end{tabular}


Akademisyenlerin ASA ĕgitim gereksinimlerinin unvanlarına göre gösterdiği farklılık

Akademisyenlerin eğitim gereksinimlerinin unvanlarına göre anlamlı düzeyde farklılaşıp farklılaşmadığını tespit etmek amacıyla ANOVA testi uygulanmıştır. Akademisyenlerin unvanlarına göre yapılan ANOVA testi sonuçlarına (Tablo 17) göre, akademisyenlerin eğitim gereksinimlerinin unvanlarına göre anlamlı düzeyde farklılaştığı tespit edilmiştir (sırasıyla $\mathrm{F}=5,227 ; \mathrm{p}<0,05 ; \mathrm{F}=6,986 ; \mathrm{p}<0,05 ; \mathrm{F}=3,388 ; \mathrm{p}<0,05)$. Farklılı̆̆ın hangi unvanlardan kaynaklandığını saptamak amacıyla Tukey testi yapılmıştır. Eğitim düzenlenmesine ilişkin (ASA'ların tanıtılacağı ve kullanımına ilişkin bilgilerin verileceği bir eğitim düzenlenmesini isterim) Tukey testi sonuçlarına göre, Arş. Gör. unvanına sahip akademisyenlerin eğitim gereksiniminin (Ort.=3,62), Prof. Dr. (Ort.=3,27) ve Dr. Öğr. Üyesi (Ort.=2,95) unvanına sahip akademisyenlere göre daha fazla olduğu ve bu farklılığın anlamlı olduğu görülmektedir.

Eğitime katılıma ilişkin (ASA'ların tanıtılması ve kullanımına ilişkin bir eğitim düzenlenirse katılmak isterim) Tukey testi sonuçlarına göre, Arş. Gör unvanına sahip akademisyenlerin eğitim gereksinimi (Ort.=3,61), Prof. Dr. (Ort.=3,13), Doç. Dr. (Ort.=2.98) ve Dr. Öğr. Üyesi (Ort.=3,00) unvanına sahip akademisyenlere göre daha fazla olduğu ve bu farklılığın anlamlı olduğu görülmektedir.

Eğitim materyaline ilişkin (ASA'ların tanıtıldığı ve kullanımına ilişkin bilgilerin verildiği bir eğitim materyalinin hazırlanmasını isterim) Tukey testi sonuçlarına göre, Arş. Gör. unvanına sahip akademisyenlerin eğitim gereksinimi (Ort.=3,69), Prof. Dr. (Ort.=3,35) unvanına sahip akademisyenlere göre daha fazla olduğu ve bu farklılığın anlamlı olduğu görülmektedir.

Eğitim düzenlenmesi, eğitime katılım ve eğitim materyali önermelerine ait bulgular ASA'lara ilişkin eğitim gereksinimi genelinde değerlendirildiğinde, Arş. Gör. unvanına sahip akademisyenlerin Prof. Dr., Doç. Dr. ve Dr. Öğr. Üyesi unvanına sahip akademisyenlerden daha fazla eğitim gereksinimi olduğu sonucuna ulaşılmaktadır.

Tablo 17

Unvanlara Göre Eğitim Gereksinimleri

\begin{tabular}{ccccccc}
\hline Boyutlar & Unvan & N & Ortalama & SS & F & p \\
\hline & Prof.Dr. & 158 & 3,27 & 1,15 & & \\
& Doç.Dr. & 50 & 3,20 & 1,05 & & \\
Eğitim düzenlenmesi & Dr.öğr.Üyesi & 38 & 2,95 & 1,31 & 5,227 &, 000 \\
& Arş.Gör. & 250 & 3,62 & 1,07 & & \\
& Öğr.Gör. & 64 & 3,53 & 1,07 & & \\
\hline \multirow{2}{*}{ Ĕgitime katılım } & Prof.Dr. & 158 & 3,13 & 1,24 & & \\
& Doç.Dr. & 50 & 2,98 & 1,08 & & \\
& Dr.Öğr.Üyesi & 38 & 3,00 & 1,36 & & \\
& Arş.Gör. & 250 & 3,61 & 1,10 & & \\
\hline
\end{tabular}




\begin{tabular}{lcccccc}
\hline & Öğr.Gör. & 64 & 3,52 & 1,08 & & \\
\hline & Prof.Dr. & 158 & 3,35 & 1,21 & & \\
& Doç.Dr. & 50 & 3,30 & 1,05 & & \\
\multirow{2}{*}{ Eğitim materyali } & Dr.Öğr.Üyesi & 38 & 3,29 & 1,21 & 3,388 &, 000 \\
& Arş.Gör. & 250 & 3,69 & 1,10 & & \\
& Öğr.Gör. & 64 & 3,66 & 1,04 & & \\
\hline
\end{tabular}

\section{Sonuç ve Öneriler}

Bilimsel iletişimin yeni bir boyut kazanmasında, SA'ların ve ASA'ların kullanımının yaygınlaşması, yayın sayılarındaki artışlar, yayın formatlarındaki değişimler, bilimsel içeriği paylaşım yöntemlerinin çoğalması, işbirliği araçlarının artması gibi etkenler rol oynamaktadır. Görünürlük ve etkinin arttırılması ve değerlendirilmesi açısından çok çeşitli olanaklar sunan ASA'lar (profil ekleme, meslektaş tanıma, literatürü takip etme, kaynak düzenleme, güncel kalma, karşılıklı soru-cevap vb.), her geçen gün gelişmekte, bilimin yayılmasında önemli bir etken olan açık erişim hareketine destek olmaktadır. Akademisyenlerin gereksinimlerini, sundukları hizmetlerle karşılamaya çalışan ASA'lar bilimsel iletişim sürecinin bir parçası haline gelmeye başlamıştır.

AÜ akademisyenlerinin ASA'ları kullanım durumlarını ve amaçlarını belirlemeyi amaçlayan bu araştırma aynı zamanda bilim insanlarına ASA'lar hakkında bilgi sunmak, bu konuda farkındalık oluşturmak ve tartışma ortamı yaratmayı hedeflenmektedir. Bu hedef doğrultusunda AÜ akademisyenlerine uygulanan anket aracılığıyla kurumsal düzeyde ASA'ların kullanımına ilişkin tutumlar ortaya çıkarılmaya çalışılmıştır. Buna göre, akademisyenlerin ASA'lara ilişkin tespit edilen tutumları aşağıdaki gibi özetlenebilir:

1. AÜ akademisyenlerinin büyük çoğunluğu SA'ları ve ASA'ları kullanmaktadırlar.

2. Akademisyenler sirasiyla Google Scholar, ResearchGate ve Academia.edu ASA'larını kullanmaktadırlar.

3. Akademisyenlerin ASA'ları en çok alanlarıyla ilgili yayınları takip etmek, alanla ilgili yenilikleri takip etmek ve akademik çalışmaları paylaşmak amaçları için kullandıkları görülmektedir.

4. AÜ akademisyenleri altmetrik göstergelerden okunma sayısı ve indirilme sayılarını önemli olarak gördüklerini belirtmektedirler. Ancak geleneksel göstergelerden atıf sayıları, akademisyenler için önem derecesi en yüksek gösterge olarak tespit edilmiştir.

5. Akademisyenlerin ASA'ları kullanmama nedenlerinin başında sırasıyla ASA'lar hakkında bilgim yok ve ASA'ları kullanmam için bir zorunluluk bulunmuyor maddeleri gelmektedir.

6. Akademisyenler ASA'ları kullanma zorluğuna ilişkin tutum puan ortalamalarına göre, en fazla düzenli kullanım sağlamada, ASA'lardan gelen bildirimleri takip etmede ve yayın isteklerini karşılamada zorlandıklarını ifade etmişlerdir. 
7. Akademisyenlerin ASA'lara ilişkin eğitim gereksinimi ile ilgili tespit edilen sonuçlara göre; ASA'ların tanıtıldığı ve kullanımına ilişkin bilgilerin verildiği bir eğitim materyalinin hazırlanmasını isterim seçeneğinin ön plana çıktığı görülmektedir.

8. Akademisyenlerin ASA kullanım tercihleri, unvanları bakımından büyük ölçüde benzerlik göstermektedir. ASA kullanımlarında, yaşlara göre anlamlı fark bulunurken unvanlara göre bulunmamaktadır. Akademisyenlerin ASA'ları kullanım durumlarının fakültelerine göre anlamlı düzeyde farklılaştığı tespit edilmiştir.

ASA'ların kullanımına ilişkin ortaya konan tutumlar, AÜ akademisyenlerinin çoğunluğunun ASA'ları kullandığını ve dolayısıyla akademisyenlerin ASA'lar konusunda farkındalığının olduğunu göstermektedir. Görünürlüğün artırılmasında etkin bir araç olarak kullanılabilecek ASA'lar kullanıcılarına kimi zaman bazı zorluklar da yaşatabilmektedir. Mevcut çalışmada yukarıda belirtildiği üzere akademisyenler; düzenli kullanım sağlamada, geri bildirimleri takip etmede ve yayın isteklerini karşılamada zorlandıklarını ifade etmişlerdir. ASA'ları kullanırken ortaya çıkan zaman sınırı konusunun çözümü olarak akademisyenlerin hangi platformu hangi nedenlerle kullanacaklarına karar vermeleri gerektiği düşünülmektedir. Böylece ASA'larda geçirilen zamanın etkin kullanımı olanaklı olacaktır.

AÜ akademisyenleri sirasiyla Google Scholar, ResearchGate ve Academia.edu ASA'larını kullanmayı tercih ettiklerini bildirmişlerdir. Daha önce yapılan araştırmalarda da yaygın olarak kullanılan ASA'ların mevcut araştırma ile benzer sonuçlara ulaşıldığı görülmektedir. Ülkemizde Bilgi ve Belge Yönetimi akademisyenlerinin (35 akademisyen) ASA'ları kullanım durumlarının incelendiği çalışmada da en sık kullanılan ASA'lar Google Scholar, ResearchGate ve Academia.edu olarak tespit edilmiştir. Nispeten küçük bir kitle üzerinde yapılan bu araştırma ile daha büyük bir kitle üzerinden yapılan mevcut araştırmanın benzer sonuçlar içerdiği görülmektedir.

Elde edilen bulguların değerlendirilmesi ve yapılan kuramsal açıklamalar 1şığında ASA'ların kullanımına ilişkin öneriler aşağıda sunulmaktadır:

- Genel olarak anket sonuçlarından elde edilen bulgular ile akademisyenlerin eğitim gereksinimi konusundaki soruya yanıtları, ASA'ların tanıtıldığı bir eğitim materyaline olan gereksinimlerini ortaya çıkarmaktadır. $\mathrm{Bu}$ doğrultuda, eğitim gereksinimini karşılamak üzere bir eğitim materyalinin hazırlanması önerilmektedir.

- Yayınların yüklenebileceği bir platform olarak ASA'lar akademisyenlerin bu platformları kurumsal depo olarak da kullanmalarına olanak sunar. Bu açıdan ASA'lar kurumsal havuzlara rakip birer platform olabilir. Bu rekabette kurumsal havuzların sistemlerini ASA'ların sunduğu hizmetlere yaklaştırması, kurumsal havuz kullanımını teşvik etmesi gerekmektedir.

- Akademisyenler hangi platformu hangi nedenlerle kullanacaklarına zaman yönetimi açısından karar vermelidir. Ayrıca akademisyenlerin ASA'ların hizmetleri ve özellikleri konusunda farkındalıkları artırılmaya çalışılmalıdır.

- Kütüphanecilerin ASA'lar konusunda bilgilendirilmesi ve bu konularda araştırmacılar için rehberler hazırlayacak düzeyde bilgiye sahip olmaları önemli görülmektedir.

Günümüzde ASA'lar, akademisyenler ve araştırmacılar arasında daha fazla tanınmakta ve bilimsel iletişim sürecinin önemli bir bileşeni olarak varlıklarını sürdürmektedir. $\mathrm{Bu}$ 
araştırma AÜ akademisyenleri ile sınırlandırılmış olmakla beraber, ASA'lar konusunda akademisyenlerin görüşlerinin tespiti ile ortaya çıkan sonuçlar, ASA'ların akademisyenler tarafından kullanımlarına ilişsin olası davranış ve tutum örüntülerini ortaya koymaktadır. ASA'ların kullanımına ilişkin farklı üniversite ve akademik kurumlara mensup akademisyenlerin yaklaşımlarını belirlemek için daha fazla çalışma yapılması önerilmektedir. Diğer üniversitelerin akademisyenleriyle gerçekleştirilecek çalışmalar ile kurumlar arasındaki farklılıklar da ortaya çıkarılabilir.

\section{Kaynakça}

Ali, M. Y. ve Richardson, J. (2018). Usage of academic social networking sites by Karachi social science faculty: Implications for academic libraries. IFLA Journal, 44(1), 23-34.

Asmi, N. A. ve Margam, M. (2018). Academic social networking sites for researchers in Central Universities of Delhi: A study of ResearchGate and Academia. Global Knowledge, Memory and Communication, 67(1/2), 91-108. https://doi.org/10.1108/GKMC-01-2017-0004

Bardakcı, S., Arslan, Ö. ve Kocadağ Ünver, T. (2018). How scholars use academic social networking services. Information Development, 34(4), 334-345.

Boyd, D. M. ve Ellison, N. B. (2007). Social network sites: Definition, history, and scholarship. Journal of Computer-Mediated Communication, 13(1), 210-230.

Büyüköztürk, Ş., K1lıç Çakmak, E., Akgün, A., Karadeniz, Ş. ve Demirel, F. (2016). Bilimsel araştırma yöntemleri. Pegem Akademi.

Chakraborty, N. (2012). Activities and reasons for using social networking sites by research scholars in NEHU: A study on Facebook and ResearchGate. Planner-2012, 19-27.

Çıngı, H. (1990). Örnekleme kuramı. Hacettepe Üniversitesi Fen Fakültesi.

El-Berry, D. K. (2015). Awareness and use of academic social networking sites by the academic staff at the South Valley University in Egypt. Journal of Library and Information Sciences, 3(2), 115132.

Elsayed, A. M. (2016). The use of academic social networks among Arab researchers. Social Science Computer Review, 34, 378-391. https://doi.org/10.1177/0894439315589146

Espinoza Vasquez, F. K. ve Caicedo Bastidas, C. E. (2015). Academic social networking sites: A comparative analysis of their services and tools. https://www.ideals.illinois.edu/handle/2142/73715

Gruzd, A. (2012). Non-academic and academic social networking sites for online scholarly communities. Social media for academics: A practical guide (ss. 21-37) içinde. Chandos Publishing.

Güler, E. ve Mutlu, M. E. (2013). Akademik personelin akademik sosyal ağları kullanım düzeyi: Anadolu Üniversitesi örneği. Ĕgitim ve Öğretim Araştırmaları Dergisi, 2(2), 72-77.

Gürbüz, S. ve Şahin, F. (2018). Sosyal bilimlerde araştırma yöntemleri (5. bs.). Seçkin Yayıncılık.

Hair, J. F., Black, W. C., Babin, B. J. ve Anderson, R. E. (2014). Multivariate data analysis (7. bs.). Pearson.

Iş1k, D. ve Gökkurt Demirtel, Ö. (2020). Bilgi ve Belge Yönetimi Bölümü akademisyenlerinin akademik sosyal ağları kullanım düzeyleri üzerine bir araştırma. Ankara Üniversitesi Sosyal Bilimler Dergisi, 11(2), 60-71.

Jeng, W., He, D. ve Jiang, J. (2015). User participation in an academic social networking service: A survey of open group users on Mendeley. Journal of the Association for Information Science and Technology, 66(5), 890-904. 
Jordan, K. (2019). From social networks to publishing platforms: A review of the history and scholarship of academic social network sites. Frontiers in Digital Humanities, 6(5). https://doi.org/10.3389/fdigh.2019.00005

Kelly, B. ve Delasalle, J. (2012). Can LinkedIn and Academia.edu enhance access to open repositories? [Bildiri]. OR2012: The 7th International Conference on Open Repositories (9/07/12-13/07/12, University of Bath) Edinburgh, İskoçya. http://eprints.lse.ac.uk/52048/

Laakso, M., Lindman, J., Shen, C., Nyman, L. ve Björk, B. C. (2017). Research output availability on academic social networks: implications for stakeholders in academic publishing. Electronic Markets, 27(2), 125-133.

Lupton, D. (2014). 'Feeling better connected': Academics' use of social media. https://www.canberra.edu.au/about-uc/faculties/arts-design/attachments2/pdf/n-andmrc/Feeling-Better-Connected-report-final.pdf

Madhusudhan, M. (2012). Use of social networking sites by research scholars of the University of Delhi: A study. International Information and Library Review, 44(2), 100-113.

Manca, S. ve Ranieri, M. (2016). "Yes for sharing, no for teaching!": Social media in academic practices. The Internet and Higher Education, 29, 63-74.

Martín-Martín, A., Orduna-Malea, E., Ayllón, J. M. ve Delgado López-Cózar, E. (2016). The counting house: Measuring those who count. Presence of Bibliometrics, Scientometrics, Informetrics, Webometrics and Altmetrics in the Google Scholar Citations, ResearcherID, ResearchGate, Mendeley \& Twitter. https://arxiv.org/abs/1602.02412

Megwalu, A. (2015). Academic social networking: A case study on users' information behavior. Current Issues in Libraries, Information Science and Related Fields (Advances in Librarianship, Vol. 39) (ss. 185-214) içinde. https://doi.org/10.1108/S0065-283020150000039014

Meishar-Tal, H. ve Pieterse, E. (2017). Why do academics use academic social networking sites? The International Review of Research in Open and Distributed Learning, 18(1), 1-22.

Nández, G. ve Borrego, Á. (2013). Use of social networks for academic purposes: A case study. The Electronic Library, 31(6), 781-791. https://doi.org/10.1108/EL-03-2012-0031

Neuman, W. L. (2014). Social research methods: Qualitative and quantitative approaches (7. bs.). Pearson Education Limited.

Ortega, J. L. (2015). Disciplinary differences in the use of academic social networking sites. Online Information Review, 39(4), 520-536.

Salahshour, M., Dahlan, H. M. ve Iahad, N. A. (2016). A case of academic social networking sites usage in Malaysia: Drivers, benefits, and barriers. International Journal of Information Technologies and Systems Approach (IJITSA), 9(2), 88-99.

Sheikh, A. (2017). Awareness and use of academic social networking websites by the faculty of CIIT. Qualitative and Quantitative Methods in Libraries, 5(1), 177-188.

Thelwall, M. ve Kousha, K. (2014). Academia.edu: Social network or academic network? Journal of the Association for Information Science and Technology, 65(4), 721-731.

Van Noorden, R. (2014). Online collaboration: Scientists and the social network. Nature News, 512(7513), 126-129.

Williams, A. E. ve Woodacre, M. A. (2016). The possibilities and perils of academic social networking sites. Online Information Review, 40(2), 282-294.

Yu, M. C., Wu, Y. C. J., Alhalabi, W., Kao, H. Y. ve Wu, W. H. (2016). ResearchGate: An effective altmetric indicator for active researchers? Computers in Human Behavior, 55, 1001-1006. 